\title{
Their stories - our history: John Fry, President of the Association 1972-4
}

Mary Nash

Honorary Research Associate, Massey University.

\section{Abstract}

This article is based on an interview with John Fry, one-time President of the Aotearoa New Zealand Association of Social Workers of which he is now a Life Member. It describes, often in his own words, one man's contribution over a 40-year period, to the social work profession and to the communities with which he worked. He is able to describe the early periods of urban drift, especially for Maori, and was respectfully working with traditional Maori communities in ways that challenged the dominant colonial attitudes present in the government institutions of the day.

\section{Introduction}

When Maurice McGregor (contemporary and highly respected member of the (A)NZASW in Christchurch) nominated John Fry as a life member for the ANZASW, he observed that 'John, in his quiet and purposeful way has done a great deal for this Association.' (McGregor, 1988, p. 1) I interviewed John Fry, NZASW President (1972-4) and Life Member of the Aotearoa New Zealand Association of Social Workers, in June 2000. This article provides an account of John Fry's life as a social worker, together with his contributions to the Association, based on that interview, augmented by some of his own records and speeches, together with McGregor's biographical notes (1988) and a variety of historical records, including past issues of the Association journal and my doctoral thesis (Nash, 1998).

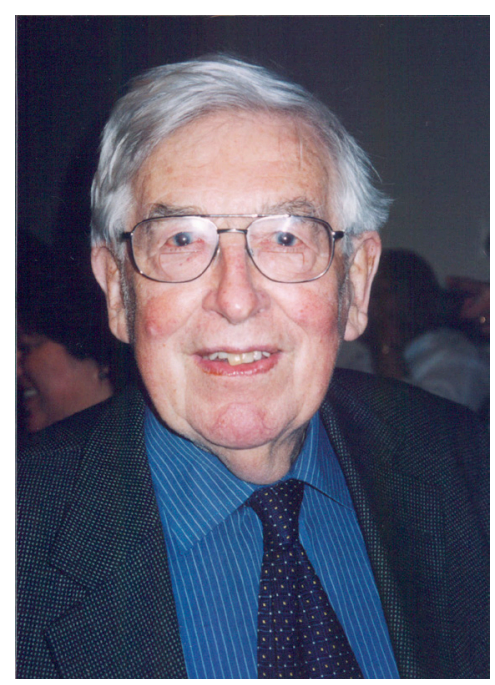

\section{John Fry 2003}

John talked about his social work career beginning in a statutory organisation as a Child Welfare Officer, and then in a non-government organisation in Anglican Social Services and finally in local government as a Christchurch City Council Community Advisor. He spoke reflectively of his involvement in the New Zealand Association of Social Workers as President during the aftermath of the closure of the Child Welfare Branch as it was merged with Social Security to become the Department of Social Welfare, and as he talked, McGregor's observations were justified.

This account of John's life as a social worker proceeds chronologically, and covers the main themes he brought 
up during the interview, which was guided by several open-ended questions about his social work career. John recalled how he was gradually drawn into social work, referring to the Depression, the aftermath of WWII and the development of social work education and professional qualifications, as well as the struggles over professionalism and registration. He reflected on the watershed years for social work when, despite all its efforts, the NZASW had to accept the formation of the Department of Social Welfare, and during his time as President, he had help to make this new social work agency function. This was despite the Association's efforts, prior to the merger, to influence the Government to adopt a different approach, informed by the carefully researched report published as 'Social Welfare at the Crossroads' (NZASW, 1971).

\section{Introduction to social work}

John described his introduction to social work as beginning in his:

... own home growing up during the depth of the depression in New Zealand in my family. My father was the vicar of a large industrial parish in Wellington and he and my mother were really very involved in people's lives ... I was very familiar with problems of people in real poverty, I was very acquainted with unemployment, the associated domestic crises ... our home from time to time included a young single girl waiting around for her baby to arrive in some sort of sheltered environment (Fry, 2000).

According to $\mathrm{O}^{\prime}$ Connor (2004, p. 36), family background and wanting to help people in need are often cited as reasons for becoming a social worker. Likewise, Cree (2003, p. 155) identified five factors which influence people to become a social worker, including childhood and family background, the influence of significant individuals and the urge to do something and make a contribution to society. John's account fits well with these findings.

As John grew up, he explained how he was faced with World War II and a desire to join the navy, a desire thwarted by his ill health at that time. He did voluntary work in the canteen of the Seaman's Institute; this was the Flying Angel Mission, and in those days, as John pointed out:

There were hundreds of mainly English merchant seamen coming ashore, spending the evening ashore in Wellington, buying food in the canteen to take back home. I heard from across the counter conversation about a fully loaded cargo ship's departure delayed by being short of crew. I seized the opportunity to go off to sea as the ship's boy, ... no medical examinations, no formalities to get in the way. I ended my wartime seafaring experience on a ship that was putting American forces ashore at the Normandy beachheads (Fry, 2000).

Early years of professional social work with the Child Welfare Division

After a stint running the Seamen's Institute, John explained that he had recognised:

...that you have to have skills and knowledge if you are going to work in people's lives. During those 12 months, there were a lot of things that came on my plate and I just felt that people weren't receiving all the help they should (Fry, 2000).

In 1953, John enrolled in the Diploma in Social Science at Victoria University College Wellington. This two-year course was the first professional social work qualifying course avail- 
able in New Zealand, and in his first year John was taught by Professor Marsh, while in his second year he had Professor Minn (as did June Kendrick, see Staniforth and Nash 2012). After qualifying as a social worker, John was employed by the Child Welfare Division of the Department of Education (a statutory agency) and he was placed in the Austin Street Boys' Home in Wellington to learn the ropes. In 1957 he was appointed to Auckland, working as a Child Welfare Officer in the largest team of social workers in the country, with Michael Lyons as the District Officer. John described his work in Auckland as:

... four years of field work involving finding foster homes for state wards and watching out for their care, writing reports for Childrens' Court and supervision of boys 10-16 years of age (Fry, 2000).

To contextualise Child Welfare work in these years, the Child Welfare Branch (later Division) was then a small part of the Education Department operating under the Child Welfare Act 1925. Between 1949 and 1950, 1,848 children went through the Children's Court. In 1951, there were 1,796 children boarded out, the number placed in employment was 566 and in residential schools for the deaf there were 298 children (Department of Statistics, 1951-52). These are small numbers in comparison with the later years, when for example, 16,624 cases were handled by the Child Welfare Division in the year ending 31/12/69. (Department of Statistics, 1971).

From 1961 to 1966 John went to Whakatane, where a new child welfare district had been carved out and he was given the responsibility for establishing the new office. John became the first District Child Welfare Officer in Whakatane. He explained that these years saw:

The beginning of the exodus from the countryside and the towns, young people were leaving school and making their way to Hamilton and Auckland and I imagine some further south too. There was a lack of employment and also there was that move into the cities. Coincidental with this, there was a rising rate in children's court appearances (Fry, 2000).

John recalled how in retrospect he felt he should have insisted on a six month course in Te Reo before moving to Whakatane, which was an area of New Zealand where there is a higher proportion of Maori men and women than elsewhere. He considered this should have been a prerequisite for the job. He remembered a lead given at that time by the then Governor General, Sir Bernard Fergusson, who was quite able to go on to a Marae and speak in Maori. John observed that he had:

A great five years in Whakatane. I was introduced to a life very different from anything I had experienced and it was a testing time, moving into remote Maori communities, having, as best one could, to be sensitive to all that was happening in Maoridom at that time (Fry, 2000).

Perhaps John's ideas were ahead of his times. In 1962, the Maori Welfare Act was passed, its aim being:

... the social and economic advancement and the promotion and maintenance of the health and general well-being of the Maori community and the facilitation of full integration of the Maori race into the social and economic life of the country (Maori Welfare Act, 1962, p. 179).

Social workers today are expected to demonstrate appropriate levels of cultural sensitivity in their practice. However, this has not always been the case and different, monocultural and 
assimilationist sensitivities were earlier deemed appropriate and acted upon by government authorities. John was alive to these issues and recalled how, shortly after arriving in the Bay of Plenty: 'The then visiting magistrate upset the community in his court by showing a complete ignorance of the Ringatu faith'. Years later, John referred to this episode in his talk to the Christchurch Rotary Club as follows:

Young men of the Ringatu faith are singing a psalm of David at first cock crow. I wake up, frightened out of my wits and then I realise that I am in the large Urewera meeting house at Ruatoki, sleeping next to my six-year-old daughter. Here, late into the previous night, the problems of the tribe's young boys and girls leaving school and drifting into the cities had been discussed. I am facing a testing time. A request to attend this hui - the only pakeha to be there, except for one academic from Auckland - came as I moved to the Bay of Plenty with Ruth and a young family, to be Whakatane's first District Child Welfare Officer. There is a troubled situation as a magistrate visits the town monthly and, in conducting the Children's Court, shows scant understanding of Maori ways and deals insensitively with offending children and parents summoned to appear with them (Fry, 2002).

John, with good advice from John Rangihau (at the time the District Maori Welfare Officer at Rotorua, and formerly a fellow student on the social work course at Victoria University, who later chaired the Ministerial Advisory Committee on a Maori Perspective for the Department of Social Welfare) and the welcome presence of his own young family, was able to diffuse the situation, and gain acceptance, both for himself and for social work.

\section{The inauguration of the New Zealand Association of Social Workers}

While still based in the Bay of Plenty, John attended the inauguration of the New Zealand Association of Social Workers at its first conference in Auckland. John described his memories of this historic occasion as leaving a 'very vivid memory of the way Merv Hancock conducted that original meeting of the Association.' He believed that, 'The people that formed that Association originally were drawn 50/50 from the voluntary organisations and from the statutory agencies', though this was to change over time. John attributed the fact that, 'there was a mixture at that meeting, to people like Jim Robb and John McCreary who had come from the academic world' (teaching on the Victoria University Social Science diploma) and who, 'to their eternal credit saw that they would contribute to this. They could see the worth of bringing people together and getting this Association off the ground.' John speculated that they could see the Association eventually advocating for increased opportunities for social work education.

John also mentioned how he had put forward a successful motion for the new course at Tiromoana (which was about to open and admit only statutory workers) to reserve some places for non-statutory practitioners, despite some opposition from a representative of the State Services Commission who was attending the conference. This was significant because it recognised the pressing need for social work practitioners to have access to social work training.

\section{Staff development and supervision}

John formed a small Council of Social Services while at Whakatane, where he was determined to promote high standards for social work. In this he was supported when, in 1966, Marriage 
Guidance Council set up a branch in Whakatane and for this they required supervision for the counsellors. John recalled how keen he was to promote this initiative and how he anticipated that supervision would benefit his own social work staff as well. In those days Marriage Guidance came under the Department of Justice. John was encouraged to go to Wellington where, after his selection, he was given supervision training which he found most useful. Here he renewed acquaintance with John Morrison, who was the chief social worker for what was then known as the Social Service Council of the Diocese of Christchurch. John applied for a position with the Social Service Council, and eventually accepted the offer of going to Timaru to open up a new Anglican Social Services office there.

\section{President of the NZASW}

John joined the NZASW Canterbury Branch executive and in 1972, was appointed as president of the New Zealand Association of Social Workers. His agency was willing to help him, 'to carry out as adequately as possible the responsibilities to the association for those two years as president, which included time away to go to the International Federation of Social Work conference which was being held in Holland in 1972' (Fry, 2000).

These were serious responsibilities, and perhaps John's calm influence on social work in the aftermath of the amalgamation of the Child Welfare Division and the Social Security Department can be seen as his particular contribution to social work. In his address to the fifth Biennial Conference of the NZASW, John referred to this amalgamation in some detail, describing how the Association had energetically opposed it, and how, with its implementation there was 'concern over the uncertain position and dissatisfaction of a considerable number of our members in the Department of Social Welfare' (Fry, 1974, p.9). John reminded conference members how in 1971 the Association had run a campaign opposing the amalgamation, arguing that if merged, the Child Welfare Division and the Social Security Department 'were likely to make unsuited bedfellows' (Fry, 1974, p.9). He referred to 'Social Welfare at the Cross-roads' (NZASW, 1971), a professional blueprint published by the Association in 1971, putting the case for a much more comprehensive merger of welfare-related organisations. For example, the blueprint not only argued against the amalgamation of the Child Welfare Division and the Income Support Service, but also put forward a comprehensive alternative which paid meticulous attention to the practicalities of implementation and which called for increased resources for the education and training of social workers.

John went on to speak of the visit of Professor John Spencer, from Edinburgh University, who had visited Branches around the country promoting the type of reorganisation of social services then occurring in Scotland. He had himself hosted the professor when he visited Timaru. John reminded the audience of the public relations consultant engaged by the Association to publicise the campaign (a fascinating campaign which illustrates many of the values and divisions within our professional association) and acknowledged the disappointment of members when the Government virtually ignored the Association's position and all the hard work that had gone into the campaign.

In fact, there has never been much acknowledgement of this interesting part of the Association's history. When McClure (1998) wrote a beautifully researched history of social security provision in Aotearoa New Zealand, the critical voice of the professional Association of Social Workers is barely referred to. Likewise, Dalley and Tennant's 1998 history of child welfare 
provision is almost blind to the role of professional social workers, more because of what she omits than from what she writes. In neither of these two commissioned histories would the social work student get an inkling of the tremendous efforts made by the NZASW on various occasions to persuade Government to consider shaping policies in particular ways.

In 1974, John was speaking of a watershed moment of our history. ${ }^{1}$ It had been his responsibility to support members of the Association, who as new employees in the new Department of Social Welfare, had to implement the policy they had battled against. The new executive of the Association (of which he was president) had immediately asked to meet the Director-General of the new department and this was to lead to regular meetings between Mr. MacKay and the Association representatives. John's speech was neither weak nor inflammatory. Instead it was critical in tone and yet pragmatic in its acceptance of a fait accompli. He stressed the fact that: 'Specialised work with families where children are at risk is not an appropriate field for economy' (Fry, 1974, p. 11), a sentiment which once again needs emphasis.

Other highlights in John's contribution to social work include his presentation of a paper at the 1972 IFSW Conference in Holland, and how, a couple of months before setting out to that, a letter came from Hong Kong from the Council of Social Services there to say that they were having a preconference seminar and asking if he would present a paper on the role of the NZ Association of Social Workers. This he agreed to do and recounted how he:

... was greatly helped in responding to that invitation by a very strong committee the association had in Wellington, that year. It was the Public Questions Committee which had some extraordinarily good people on it, there was Avery Jack, Peter Bygate, Ian Jenkins, Marjorie Heads, Brian Manchester, Erica Brodie and others, and they were instrumental in sending off ahead a very good account of the stage which the NZ ASW was at. This included something which clearly was of immense interest to young and trainee social workers in Hong Kong who were present at that seminar on the afternoon that I delivered the paper because it spoke of how NZ social workers in their day to day work were able to gain the ear of their employers and it described the mechanisms that were in place as an association for meeting with the Minister of Social Welfare and Heads of Government Departments; now to this day I can see in my mind's eye at the back of the room, a 'demonstration' being staged by young social workers. In Hong Kong there seemed to be social workers everywhere, lots of voluntary agencies and government agencies. It was a rigidly controlled Crown Colony and the fact that it was possible for New Zealand social workers to get their voices through in this way was seen as exciting and almost revolutionary (Fry, 2000).

Another event that stood out in John's memory, and is still recalled by those who were present was how the Dunedin Branch invited Bob Hawke (later prime minister of Australia) to be the guest speaker at the 1974 conference. John described how:

At that time Bob Hawke was undoubtedly the best known trade unionist in Australia ... and he was under threat for his life from terrorists (he was supporting Jewish women involved in

1 For a detailed account of the 1971 campaign against the reorganisation of the social services see Nash, M. (1998). People, policies and practice. Social work education in Aoteroa/New Zealand from 1949-1995. Unpublished doctoral dissertation. Massey University, Palmerston North, New Zealand.

On the international scene, two publications relating to restructuring social service delivery systems, the Kilbrandon Report (1964) in Scotland and the Seebohm Report (1968) in England and Wales, had advocated amalgamating statutory social service provision into one all-purpose department, where generic social workers would assist clients. 
the fighting in Israel and the target of some hostility as a result) ... I can remember that our conference got under way in Dunedin and the very first day it was given some slight element of excitement because the local police came down and examined the access to the hostels and ran a sort of tape measure over the place and then I think in the late afternoon it was the beginning of the conference, Maurice McGregor who was there with me, had to go out to the airport to meet Bob Hawke ... and very quickly Bob Hawke established himself as the most likeable man and absolutely threw himself into our two or three days of conference. ... There is no doubt about it that having Bob Hawke was something that future conferences might keep in mind. ... There is a quote from him, 'we must be activists in the sense of not accepting something as necessarily so just because it is done', and at the president's dinner according to my notes, Bob Hawke certainly put his words into action when he ably led the whole conference in singing 'Solidarity Forever' and formed the head of a long conga singing throughout the university premises, 'I am a union man' (Fry, 2000).

The photograph below depicts John with Bob Hawke, at the Dunedin Conference, 1974. The character sitting behind John and Bob Hawke is the plain clothes policeman assigned to look after Hawke. When John asked him how he was chosen for this task, he said that he was selected to fit in at a social workers' conference!

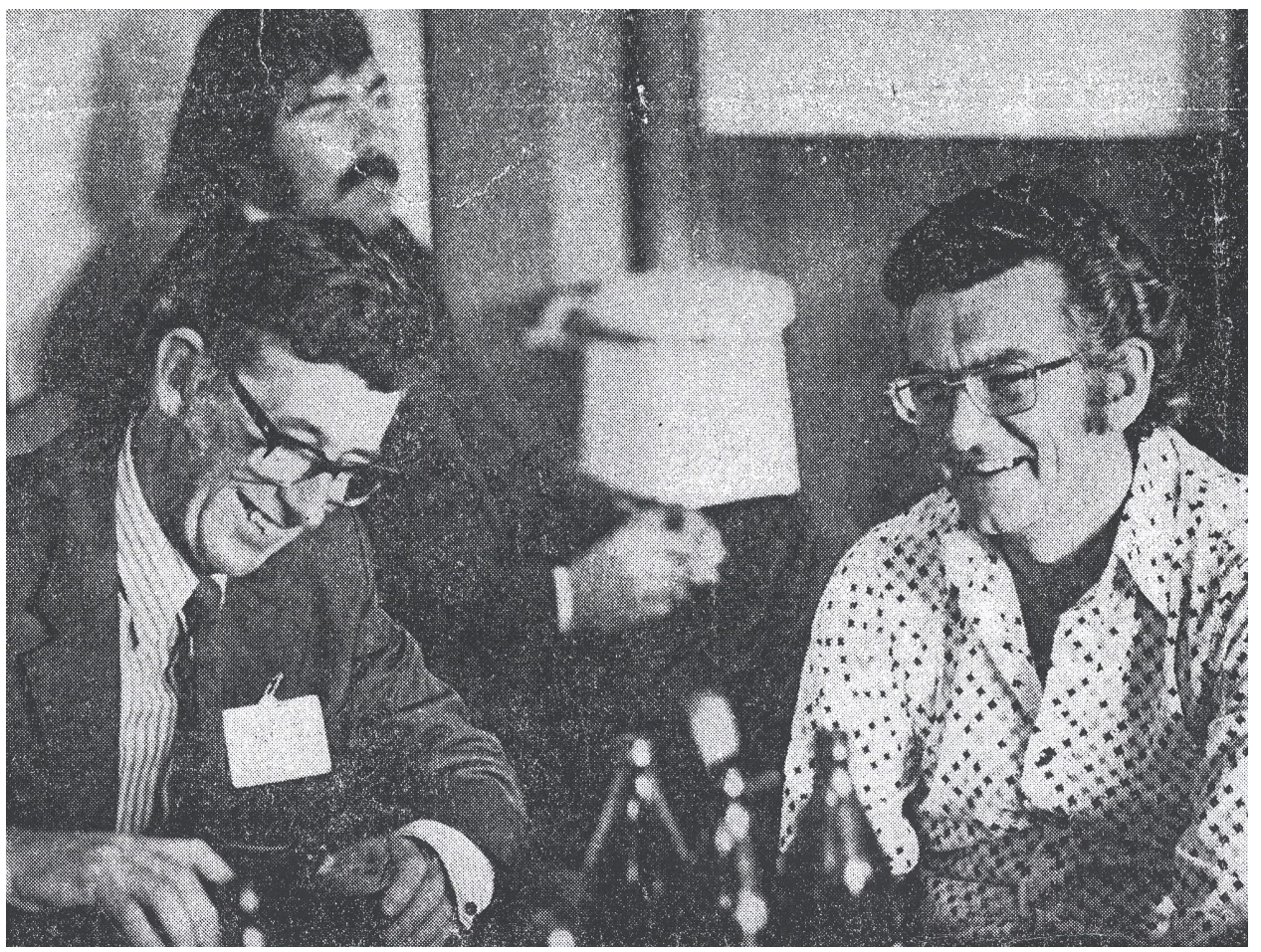

\section{Community Advisor with Christchurch City Council, 1973-84}

During our interview, John had said little about his post-presidential career in the social services. Like several others whom I have interviewed, John was kind enough to give me supplementary papers and additional thoughts relating to the interview, among which is a reflective note stating that: 


\begin{abstract}
My working life in social/community services was carried out from three quite distinct bases - statutory, voluntary organisation, local government. I rate my most productive time (access to resources, influencing colleagues in related fields, eg town planning, housing), as the ten years in local government, and feel gratitude to NZASW members who saw the opportunities of getting workers into that structure and supported the initial moves. In fact, it was Maurice McGregor who clipped the original newspaper advertisement for a 'welfare worker' at the Christchurch City Council and mailed it to me while I was away in Holland at the IFSW meeting.
\end{abstract}

In nominating John for life membership, Maurice McGregor observed that:

...in Christchurch social workers remembered John Fry for the work he has done with the Christchurch City Council, first of all as a Community Advisor and later, when there were seven community workers, as Head of the Division of Community Services. John developed a publication, 'HELP' which was a directory of community activities, and was involved with the local Citizens' Advice Bureau, where he was, for a time, local Chairperson and National Vice-President (McGregor, 1988).

\title{
Conclusion
}

The article raises substantive questions about the role of the Association today, as well as raising questions about our relationship with the government sector. It is both challenging and sobering to consider the similar issues we still face as a professional body and as individual social workers all these years on. The struggle for social justice continues, and advocacy and policy development remain critical for every social work practitioner. Looking back over John's career he was something of an initiator. He opened up the new Child Welfare District office in Whakatane, where he also introduced supervision, through the Marriage Guidance Council, to counsellors and social workers. Later, he opened the Anglican Social Services office for South Canterbury in Timaru, and then he saw the Association of Social Workers through its first years in the Department of Social Welfare. In retirement, John has continued to be an engaged and active member of the Association, attending conferences and supporting the local branch. His story (of which I have probably only touched the surface), supports the title of his talk to the Christchurch Rotary Club in 2002: 'Life is an adventure.'

Methodological notes: I am grateful to John Fry for correcting errors and giving me permission to publish this article. I have edited the spoken word in order to make the text flow more smoothly and to cluster ideas together. I have done so as sparingly as possible. I have tried to use the correct title for the Aotearoa New Zealand Association of Social Workers, as it was used in the period referred to, or else inclusive of its current and original name '(A) NZASW'. Finally, I am grateful to the reviewers for their comments, and they will notice that I have incorporated some of their suggestions and observations into this article.

\section{References}

Cree, V.A. (Ed). (2003) Becoming a social worker. London: Routledge.

Dalley, B. (1998). Family matters. Auckland: Auckland University Press in association with the Historical Branch, Department of Internal Affairs.

Department of Statistics. (1951-52). The New Zealand Official Year-Book, 1951-52. Retrieved from http: / / www3.stats. govt.nz/New_Zealand_Official_Yearbooks/1951-52/NZOYB_1951-52.html\#idchapter_1_66844, on 14/3/2014.

Department of Statistics. (1971). The New Zealand Official Year-Book, 1971. Retrieved from http:/ / www3.stats.govt. nz/New_Zealand_Official_Yearbooks/1971/NZOYB_1971.html\#idsect1_1_60013, on 14/3/2014.

Fry, J. (1974) Extracts from the president's opening address at the 5 th biennial conference. The New Zealand Social Worker, 10(1), 5-13.

Fry, J. (2000). Recorded interview with Mary Nash, 29/6/2000. Held by Mary Nash. 
Fry, J. (2002). Life is an adventure. Talk to Christchurch Rotary Club, 16/4/02. Copy held by Mary Nash.

McClure, M. (1998). A civilised community: A history of social security in New Zealand from 1898-1998. Auckland: Auckland University Press in association with the Historical Branch, Department of Internal Affairs.

McGregor, M. (1988). A biographical note on John Fry. Copy held by Mary Nash.

Nash, M. (1998). People, policies and practice: Social work education in Aotearoa/New Zealand from 1949-1995. Massey University, Palmerston North: Unpublished PhD thesis.

New Zealand Association of Social Workers. (1971) Social welfare at the crossroads: Report on social welfare in New Zealand. Wellington: New Zealand Association of Social Workers.

O'Connor, J. (2004). Who are New Zealand Social Workers? A look at journeys into social work. A research project presented in partial fulfillment of the requirements of the Masters of Social Work Applied Degree at Massey University, Palmerston North.

Report of the Committee on Children and Young Persons (Scotland) (Kilbrandon Report) (1964). Cmnd. 2306, Edinburgh, H.M.S.O.

Report of the Committee on Local Authority and Allied Personal Social Services (Seebohm Report) (1968). Cmnd. 3703, London , H.M.S.O.

Staniforth, B. and Nash, M. (2012). Their stories - our history, bringing a myriad of gifts, June Kendrick. Social Work Review, 24(2), 27-36. 